\title{
ORGANIZATIONAL AND MANAGERIAL ASPECTS OF ECONOMIC EFFICIENCY OF ENTERPRISES (FOR EXAMPLE, SEAPORTS)
}

\author{
Yevhenia Boiko', Olena Ishchenko², Yuliia Barabanova ${ }^{3}$
}

\begin{abstract}
It is established that maritime infrastructure is an important component of the economy of Ukraine, the effective functioning of which is a necessary factor of the determination of Ukraine as a maritime state, the sustainable development of its transport and road complex. It is proved that the efficiency of ports is of utmost importance for the economy of Ukraine, as more than $60 \%$ of the Ukrainian products are exported by sea. A more detailed analysis of the efficiency of the seaports is important not only from the commercial point of view of Ukraine as a whole and one particular seaport, but also from the point of view of economic policy in the port industry. It is proved that there is an urgent need to introduce effective and timely reforms of the maritime economy, based on the identification of a complex of factors influencing the processes of strategic development of seaports of Ukraine and aimed at improving the system of management of state-owned enterprises, taking into account world experience, upswinging state regulation of port business, improving the competitiveness of the port business, upgrading the role of maritime transport in using the potential of international transport corridors. The variants of the efficiency criterion of the seaport have been developed, allowing to evaluate the activity of the port in different conditions and to compare the activity of different ports with each other. The efficiency of the criteria is checked, their interrelation is shown and recommendations for their calculation are given. With the help of the offered criteria work efficiency of the Ukrainian and foreign ports is compared, ways of development of the Ukrainian ports are specified. An analysis of the publications and studies carried out on the topic of evaluating port performance shows that most researchers pay attention to economic evaluation criteria. Technical criteria for the port's operational efficiency are considered less frequently and in many cases are not adapted for integral assessment due to the lack of sufficient information. The main aim of the article is to compare the performance of the Ukrainian and foreign ports. Research objectives: to develop objective in-kind performance indicators for ports, allowing them to evaluate port activities in different conditions and compare the activities of different ports with each other; to check the operability of port performance indicators; to compare the performance of Ukrainian and foreign ports with each other using the proposed natural indicators.
\end{abstract}

Key words: economic efficiency, efficiency ratio, economic activity, economic result, seaport.

JEL Classification: R12, G24

\section{Introduction}

The efficiency of enterprises, including ports, is usually evaluated using economic criteria. The effectiveness of the seaport is measured by an indicator that establishes the relationship between the result of work and the resources expended to achieve this result. Work efficiency is usually expressed in relative terms. At the same time, the achieved work result is in the relative numerator and the costs of achieving the work result are in the denominator. A larger value of the indicator in this case corresponds to a greater efficiency (Chornopyska, 2008).

\footnotetext{
Corresponding author:

${ }^{1}$ Admiral Makarov National University of Shipbuilding, Ukraine.

E-mail: yevheniaboiko@gmail.com

${ }^{2}$ Admiral Makarov National University of Shipbuilding, Ukraine.

E-mail: management@nuos.edu.ua

${ }^{3}$ Admiral Makarov National University of Shipbuilding, Ukraine.

E-mail: juliatrushliakova@gmail.com
}

Measurement of costs and the result of the port can be performed in cost or in-kind (technical) indicators. When using cost values, the efficiency indicator is called economic. An example of an economic performance indicator is profitability. When using technical quantities, the efficiency indicator is called natural or technical.

The economic performance of the port can be calculated subject to the availability of information on the profit made by the port over a certain period of activity. Various factors, including political ones, influence port profit margins. The profit of the 
enterprise is connected with the payment of taxes and in some cases, for obvious reasons, information about the profit is provided in a distorted form. To conduct a comparative analysis of port activities in different countries and economic conditions, it seems more appropriate to use in-kind performance indicators.

N.K. Nikolaeva and A.L. Davydova offer the seaport performance factor to calculate taking into account the technical equipment of the port, port adaptability to innovations and environmental conditions (Nikolaeva, Davydova, 2004).

The port's adaptability to innovations and environmental conditions are interconnected, since innovations are often caused by changes in the external environment. For this reason, in the numerator of the formula for calculating the coefficient of efficiency of the seaport, the coefficients of port adaptability to innovations and environmental conditions are summarized. The authors of the study do not indicate how to evaluate the above mentioned adaptability for a port correctly.

The coefficient of technical equipment of the port can be calculated if there is detailed information about the technical equipment of the port, which in some cases is difficult or impossible at all. The reference literature on ports provides, at best, information about the crane equipment of the port without specifying the characteristics of warehouse equipment, which affects the port's technical equipment quite strongly.

P.E. Zhelezkova recommends using the following indicators when assessing the port's operational efficiency: technical equipment, cargo turnover, profitability, liquidity (Zhelezkova, 2016).

The main indicators of the seaports work, according to the practice of port facilities, are cargo turnover and cargo handling. Chornopyska N.V. suggests the integrated use of performance indicators of a logistics company. The author has shown that for the formation of the indicators system of the enterprise's activity, it is necessary to create a database. After creating a database and the indicators system of the enterprise's activity, the researcher recommends applying the benchmarking procedure to analyze the enterprise's activities (Chornopyska, 2008).

Of particular note is the author's proposal to subdivide the performance indicators of an enterprise into indicators that characterize the enterprise and indicators that reflect the activities of the enterprise. In assessing the effectiveness of the port, this approach may be useful in some cases.

\section{A methodological toolkit for assessing the cost-effectiveness of seaports}

The effectiveness of the seaport is measured by an indicator that establishes the relationship between the result of work and the resources expended to achieve this result. Work efficiency is usually expressed in relative terms. At the same time, the achieved work result is in the relative numerator and the costs of achieving the work result are in the denominator. The greater the value of the indicator in this case corresponds to greater work efficiency (Chornopyska, 2008).

The measurement of costs and the result of work can be performed in value or in-kind (technical) quantities. When using financial variables, it is customary to call the performance indicator economic. An example of an economic performance indicator is profitability. When using technical quantities, it is customary to call the performance indicator natural or technical.

Let us consider the in-kind (technical) indicators of the seaport. The technical performance indicators of the seaport, in turn, are divided into differential and integral indicators of the seaport performance. Differential performance indicators of the seaport contain two values: the achieved result of work and the technical parameter of the port, ensuring the achievement of the result of work. The integrated indicators of the seaport performance in the numerator or denominator contain a number of values characterizing the achieved results and technical parameters of the port. Moreover, there are aggregates of quantities reduced to the same dimension in the numerator and denominator of the fraction.

Differential technical indicators of the seaport performance are inherently separate technical indicators of the seaport performance. Let us consider a number of relative values, which from different sides characterize the efficiency of the seaport. The result of the seaport, based on the destination of the port, is the transshipment of goods from one mode of transport to another (from one transport unit to another), storage and sorting of cargo, the formation of freight consignments.

In the world practice, when evaluating the port's operational efficiency, it is customary to consider the port's annual cargo turnover as a result of the work (Entsiklopediya statisticheskih terminov). As a technical parameter of the port, providing port cargo turnover, one of the following values can be used: length of the berth line, area of the territory, water area, area of storage facilities, total load capacity of the port's cargo devices.

The indicator is calculated by the formula:

$$
k_{e f_{1}}=\frac{Q}{L}
$$

where: $Q$ is the annual cargo turnover of the seaport, $L$ is the length of the berth line, area of the territory, water area, area of storage facilities, total capacity of the port's cargo devices.

In each case, the indicator can be detailed. For example, when using the length of the berth line, divide the berths into deep-sea and shallow ones, when using the area of the warehouses, divide the berths into open and closed or universal and special.

The indicator quantitatively characterizes the cargo turnover of the seaport per unit technical parameter of the port. 
A special place is occupied by an indicator determined by the formula:

$$
k_{\text {ef } 2}=\frac{Q}{Q_{P}}
$$

where: $Q$ is the annual cargo turnover of the seaport, $Q_{p}$ is the annual throughput of the port.

The indicator quantitatively characterizes the cargo turnover of the seaport, referred to the port capacity. In other words, the indicator characterizes the degree of use of port facilities in the current period. The indicator is useful in assessing the port's ability to urgently increase transshipment.

The value of the indicator $k_{e f 2}$ for the ports of Ukraine is shown in table 1 .

The only port in Ukraine, the port capacity of which is fully loaded, is the port of Berdyansk. The remaining ports have capacities that can be quickly deployed without attracting significant investments. However, the capabilities of the transport systems that serve the ports should be further evaluated. Thus, railways and roads are often not able to provide cargo flows with the maximum use of port facilities.

The above differential indicators of the seaport performance are convenient when analyzing the port model for sensitivity to changes in port technical parameters. The indicators are effective at ports comparable in terms of cargo turnover structure and allow assessing the impact of each parameter on the port cargo turnover separately.

Integrated indicators of the seaport's operational efficiency allow us to compare the operational efficiency of different ports in terms of cargo turnover. A comprehensive (integral) indicator of the port's operational efficiency is formed by combining individual (differential) indicators.

A comprehensive indicator of the seaport's operational efficiency is expressed as a coefficient. The achieved result of the work is in the numerator of the relative value: the annual cargo turnover of the port in physical units. The main technical parameters of the seaport are in the denominator.

A comprehensive indicator of the performance of a specialized seaport is different from that for a universal port. Comparison of the performance of universal seaports is associated with the need to take into account the structure of cargo handled by ports. Therefore, a comprehensive indicator of the efficiency of the seaport should, whenever possible, take into account the specifics of different ports and ensure the compatibility of ports of different specialization and structure.

To take into account the specifics of the port, you must have the source data characterizing the port. Some of the technical characteristics of the seaport are not reported, some of the characteristics are given in a form that complicates or makes impossible a comparative assessment of the port with other ports.

A number of options are proposed for calculating a comprehensive indicator of the seaport performance.

A seaport performance indicator that takes into account the area of the berth line and the area of port warehouses is proposed:

$$
k_{i f_{1}}=\frac{Q}{L \cdot H+k \cdot S_{s k}}
$$

where: $Q$ is the annual cargo turnover of the seaport, $L$ is the length of the berth line of the port, $H$ is the weighted average depth of the berth line of the port, $k$ is the weighted average coefficient of comparability of the berth and warehouse, $S_{s k}$ is the total area of port warehouses.

The weighted average depth of the berth line of the port is determined by the arithmetic mean formula for the depths of the port at the berths, where the length of the berth is the weight to each depth of the berth.

Table 1

The degree of Ukraine ports use

\begin{tabular}{|c|l|c|c|c|c|c|}
\hline № & \multicolumn{1}{|c|}{ Port name } & $\begin{array}{c}\text { Cargo turnover, } \\
\text { million tons }\end{array}$ & $\begin{array}{c}\text { Throughput, million } \\
\text { tons }\end{array}$ & $\begin{array}{c}\text { The length of the } \\
\text { berths, km }\end{array}$ & Depth, m & $k_{\text {ef } 2}$ \\
\hline 1 & Yuzhny & 39.3 & 61.5 & 5.9 & 17.5 & 0.639 \\
\hline 2 & Odessa & 25.3 & 56 & 9 & 14 & 0.452 \\
\hline 3 & Mykolaiv & 22.4 & 29.6 & 3.8 & 11.2 & 0.757 \\
\hline 4 & Chornomorsk & 15.9 & 64.3 & 6 & 14 & 0.247 \\
\hline 5 & Mariupol & 7.6 & 18.8 & 3.9 & 9.75 & 0.404 \\
\hline 6 & Belgorod Dnestrovsky & 0.46 & 1.1 & 1.1 & 2.8 & 0.418 \\
\hline 7 & Berdyansk & 3.8 & 3.7 & 1.6 & 8.4 & 1.027 \\
\hline 8 & Izmail & 5.7 & 9.3 & 2.6 & 8 & 0.613 \\
\hline 9 & Olvia & 6.5 & 1.5 & 1.5 & 11.5 & 0.121 \\
\hline 10 & Reni & 0.97 & 8 & 3.6 & 7.5 & 0.121 \\
\hline 11 & Skadovsk & 0.03 & 1.3 & 0.8 & 6 & 0.023 \\
\hline 12 & Ust-Dunaisk & 0.03 & 5 & 0.15 & 6 & 0.006 \\
\hline 13 & Kherson & 3.7 & 8 & & 9.6 & 0.463 \\
\hline & Average & & & & & 0.450 \\
\hline
\end{tabular}

Source: the table is constructed by the authors based on the information (Strategy for the development of Ukrainian seaports for the period until 2038) 
It would be methodologically correct to take into account when calculating the indicator, not the depth at the berth, but the height of the berth wall. However, data on the height of the berth wall in most cases are not available. At the same time, there is a rather close relationship between the depth at the berth and the height of the berth wall.

In some cases, instead of the weighted average depth of the port berth line, it is possible to take the greatest depth at the port berth. The distribution of vessels accepted by the port by sediment may turn out to be similar to the distribution of berths by depth, which is explained by a well-thought-out policy for the development of the port. In this case, the port will make maximum use of its capabilities, and the proposed formula will objectively reflect the degree of use of port capabilities.

The weighted average coefficient of comparability of the berth and warehouse $\mathrm{k}$ takes into account the unevenness of the construction, operation and cost of the berthing and storage facilities. Further detailing of the indicator is possible due to the division of port warehouses by categories (open, closed, specialized).

In some cases, statistics on port activities are provided separately for cargo turnover in tons and for container transshipment in TEU conventional units. In this case, to calculate the coefficient of efficiency of the seaport, the formula is proposed:

$$
k_{i f_{2}}=\frac{Q+k_{1} \cdot Q_{k}}{L \cdot H+k_{2} \cdot S_{s k}}
$$

where: $Q$ is the annual cargo turnover of the seaport for cargo other than container cargo, mln tons; $Q_{k}$ is the annual seaport cargo turnover per container cargo, thousand TEU; $k_{1}$ is the weighted average coefficient of comparability of containers and general cargo, million tons / thousand TEU; $L$ is the length of the berth line of the port, $\mathrm{km}$; $H$ is the weighted average depth of the berth line of the port, $\mathrm{m}$; $k_{2}$ is the weighted average coefficient of comparability of the berth and warehouse; $S_{s k}$ is the total area of port warehouses.

The coefficient characterizes the efficiency of the use of berths and warehouses of the port. The achieved result of the port is expressed in port turnover. Port cargo turnover consists of traditional cargo and specialized cargo, i.e. containers handled by the port. The port's traditional cargo turnover is measured in tons, and the port container turnover in arbitrary units is TEU. To compare the components of the result of the port's work, a weighted average coefficient of comparability of containers and general cargoes is introduced with a dimension of million tons / thousand TEU.

For a more detailed account of the storage facilities of the port, the coefficient of the seaport performance is proposed to be calculated by the formula:

$$
k_{i f_{3}}=\frac{Q+k_{1} \cdot Q_{k}}{L \cdot H+k_{2} \cdot S_{S k}+k_{2} \cdot S_{k}+k_{2} \cdot(V)^{\frac{2}{3}}}
$$

where: $Q$ is the annual cargo turnover of the seaport for cargo other than container, million tons; $Q_{k}$ is the annual seaport cargo turnover per container cargo, thousand TEU; $k_{1}$ is the weighted average coefficient of comparability of containers and general cargo, million tons / thousand TEU; $L$ is the length of the berth line of the port, $\mathrm{km} ; \mathrm{H}$ is the weighted average depth of the berth line of the port, $\mathrm{m} ; k_{2}$ is the weighted average coefficient of comparability of the berth and warehouse, except for the container warehouse; $k_{3}$ is the weighted average coefficient of comparability of the berth and container warehouse; $k_{4}$ is the weighted average coefficient of comparability of the berth and capacity for the storage of bulk and / or bulk cargo;

$S_{s k}$ is the total area of the port's warehouses, in addition to container warehouses and containers for storing bulk and / or liquid cargo, thousand $\mathrm{m}^{2} ; s_{k}$ is the total area of port container warehouses, thousand $\mathrm{m}^{2} ; V$ is the total volume of port capacities for the storage of bulk and / or bulk cargo, thousand $\mathrm{m}^{3}$.

The coefficient $k_{i f 3}$ differs from the coefficient $k_{i f 2}$ in that the storage capacity is detailed by dividing the warehouses into warehouses for general and bulk cargoes, warehouses for containerized cargo, warehouses for storing bulk cargoes in containers, warehouses for storing bulk cargoes. Further detailing of the indicator is possible due to the division of the port warehouses for general and bulk cargo into open and closed warehouses.

Let us consider the use of formulas to calculate the coefficient of marine efficiency on the examples of several ports of the southern region of Ukraine. The Information about ports and the values of the coefficient of efficiency of seaports are given in table 2 .

For example, taking into account the limited initial information, the variant of the integral coefficient of the seaport's operational efficiency $k_{i f_{1}}$, is used, which is determined by formula (3).

\section{Economic diagnostics of efficiency of activity of seaports}

The results of calculating the efficiency coefficient for the three ports of the southern region are shown in table 2 .

In accordance with the integrated efficiency coefficient of the seaport $k_{i f_{1}}$ the port of Yuzhny was most effectively used in 2017 . The indicated result has an explanation: the modern port is not burdened with excess berths and warehouses or is not limited to berths and warehouses. The second place occupied by the port of Odessa is explained by a high level of management compared to the port of Chornomorsk.

The seaport performance factor may be calculated in another way. In the numerator of the formula for calculating the coefficient, the port capacity is substituted instead of the annual cargo turnover of the seaport. In this case, the indicator should be called the maximum coefficient of efficiency of the seaport. 
Table 2

Data on the ports of the southern region of Ukraine

\begin{tabular}{|l|c|c|c|c|c|c|c|}
\hline № & Port name & Q million tons & $\begin{array}{c}L, \\
\mathrm{Km}\end{array}$ & $\begin{array}{c}H, \\
\mathrm{~m}\end{array}$ & $\begin{array}{c}S_{s k}, \\
\text { thousand } \mathrm{m}^{2}\end{array}$ & $\mathrm{k}$ & $\mathrm{k}_{\mathrm{ifl}}$ \\
\hline 1 & Yuzhny & 15.07 & 2.7 & 14 & 187.5 & 0.0143 & 0.372 \\
\hline 2 & Odessa & 25.59 & 10.2 & 9.6 & 485.49 & 0.0143 & 0.244 \\
\hline 3 & Chornomorsk & 14.57 & 6 & 10.75 & 602 & 0.0143 & 0.199 \\
\hline & Average & & & & & & 0.272 \\
\hline
\end{tabular}

Source: the table is built by the authors based on the information (Ports of Ukraine)

Table 3

Data on the ports of the southern region of Ukraine

\begin{tabular}{|c|c|c|c|c|c|c|c|}
\hline № & Port name & $Q_{p}$, million tons & $\begin{array}{c}L, \\
\mathrm{Km}\end{array}$ & $\begin{array}{c}H, \\
\mathrm{~m}\end{array}$ & $\begin{array}{c}S_{\text {sk }} \\
\text { thousand } \mathrm{m}^{2}\end{array}$ & $\mathrm{k}$ & $\mathrm{k}_{\text {iflMAx }}$ \\
\hline 1 & Yuzhny & 61.5 & 2.7 & 14 & 187.5 & 0.0143 & 1.519 \\
\hline 2 & Odessa & 56 & 10.2 & 9.6 & 485.49 & 0.0143 & 0.534 \\
\hline 3 & Chornomorsk & 64.3 & 6 & 10.75 & 602 & 0.0143 & 0.880 \\
\hline & Average & & & & & & 0.978 \\
\hline
\end{tabular}

Source: the table is built by the authors based on the information (Strategy for the development of Ukrainian seaports for the period until 2038)

The results of calculating the maximum efficiency coefficient for three seaports of the southern region are given in the table 3.

In accordance with the maximum value of the seaport performance coefficient, the port of Yuzhny has the greatest prospects for increasing cargo turnover, and the port of Odessa has the least prospects.

Consider the use of formula (4) for calculating the efficiency coefficient of the seaport $k_{i j 2}$ using the example of the port of Odessa. The values of the efficiency coefficient of the seaport of Odessa with and without container transshipment are shown in table 4 (Ports of Ukraine. Odessa Seaport).

The coefficient characterizes the efficiency of the use of berths and warehouses of the port. The achieved result of the port is expressed by the aggregate, consisting of the cargo turnover of the port and the number of containers overloaded by the port. Cargo turnover is measured in tons, and container turnover in conventional units of TEU. To compare the components of the result of the work, a weighted average coefficient of comparability of containers and general cargoes is introduced, having a dimension of million tons / thousand. TEU.
The efficiency coefficient of the seaport $k_{i f_{2}}$ using the example of the port of Odessa in 2018 allows us to assess the contribution of the container terminal to the port: $(0.182-0.142) / 0.182=0.22$.

Using the performance indicators of the seaport $k_{e f 1}$ and $k_{i f 1}$ we compare a number of Ukrainian and foreign ports.

For foreign ports, it is not possible to find out the storage area due to lack of data. For this reason, the performance indicators of seaport $k_{e f_{1}}$ and $k_{i f_{3}}$ are calculated in Table 5 for Ukrainian ports without warehouse area.

Tables 6, 7, 8 summarize the results of calculating the performance of the seaport $k_{e f 1}$ and $k_{i f 1}$ for a number of foreign ports.

Table 9 shows the average values of the port characteristics of Ukraine, Europe, Canada and the USA.

For Tables 5 to 8 , the correlation coefficient between the performance indicators of the seaport $k_{\text {ef } 1}$ and $k_{i f 3}$. The average correlation coefficient for the ports of Europe, Canada and the USA is 0.93 . The high value of the correlation coefficient indicates a close correlation between the performance indicators of seaport $k_{e f 1}$ and $k_{i f 3}$, which, in the absence of data to calculate the indicator $k_{i f 3}$ is sufficiently reliable to use the indicator $k_{e f 1}$. For the ports of Ukraine such replacement is unacceptable.

Table 4

Data on the activities of the Odessa Sea Port in 2018

\begin{tabular}{|c|c|c|c|c|c|c|c|c|c|}
\hline № & Port name & $\begin{array}{c}\text { Q million } \\
\text { tons }\end{array}$ & $\begin{array}{c}Q_{k}, \\
\text { thousands } \\
\text { TEU }\end{array}$ & $L, \mathrm{Km}$ & $H, \mathrm{~m}$ & $\begin{array}{c}S_{s k} \text {, thousand } \\
\mathrm{m}^{2}\end{array}$ & $\mathrm{k}_{1}$ & $\mathrm{k}_{2}$ & $\mathrm{k}_{\mathrm{i} 22}$ \\
\hline 1 & Odessa & 21.698 & 598.6 & 10.2 & 15 & 485.49 & 0.0102 & 0.0143 & 0.182 \\
\hline 2 & Odessa* & 21.698 & 0 & 10.2 & 15 & 485.49 & 0.0102 & 0.0143 & 0.142 \\
\hline
\end{tabular}

${ }^{*}$ Note. The second row of the table shows the parameters of the port of Odessa without taking into account the results of the container terminal. Source: the table is built by the authors based on the information (Ports of Ukraine. Odessa Seaport) 
Vol. 5, No. 5, 2019

Table 5

Data on ports of Ukraine

\begin{tabular}{|c|l|c|c|c|c|c|}
\hline № & \multicolumn{1}{|c|}{ Port name } & Q million tons & $\begin{array}{c}L, \\
\mathrm{Km}\end{array}$ & $\begin{array}{c}H, \\
\mathrm{~m}\end{array}$ & $k_{\text {ef } 1}$ & $k_{i f 1}$ \\
\hline 1 & Yuzhny & 39,3 & 5,9 & 17,5 & 10,42 & 0,381 \\
\hline 2 & Odessa & 25,3 & 9 & 14 & 6,22 & 0,201 \\
\hline 3 & Mykolaiv & 22,4 & 3,8 & 11,2 & 7,79 & 0,526 \\
\hline 4 & Chornomorsk & 15,9 & 6 & 14 & 10,72 & 0,189 \\
\hline 5 & Mariupol & 7,6 & 3,9 & 9,75 & 4,82 & 0,200 \\
\hline 6 & Berdyansk & 3,8 & 1,6 & 8,4 & 2,31 & 0,283 \\
\hline 7 & Izmail & 5,7 & 2,6 & 8 & 3,58 & 0,274 \\
\hline 8 & Olvia & 6,5 & 1,5 & 11,5 & 6,33 & 0,377 \\
\hline 9 & Kherson & 3,7 & 1,5 & 9,6 & 5,33 & 0,257 \\
\hline & \multicolumn{1}{|c|}{ Average } & 14,47 & 3,98 & 11,55 & 6,392 & 0,299 \\
\hline
\end{tabular}

Source: the table was built by the authors on the basis of the information (Strategy for the development of Ukrainian seaports for the period until 2038)

Table 6

Data on European ports

\begin{tabular}{|c|l|c|c|c|c|c|}
\hline № & \multicolumn{1}{|c|}{ Port name } & Q million tons & $\begin{array}{c}L, \\
\mathrm{Km}\end{array}$ & $\begin{array}{c}H, \\
\mathrm{~m}\end{array}$ & $k_{\text {ef } 1}$ & $k_{\text {ff3 }}$ \\
\hline 1 & Antwerp & 180 & 100 & 11.25 & 1.80 & 0.160 \\
\hline 2 & Hamburg & 54.5 & 43 & 15 & 1.27 & 0.084 \\
\hline 3 & Le Havre & 48.2 & 27.5 & 15 & 1.75 & 0.117 \\
\hline 4 & Marseille & 180 & 26 & 15 & 6.92 & 0.462 \\
\hline 5 & Rotterdam & 433 & 40 & 22 & 10.83 & 0.492 \\
\hline 6 & London & 10.2 & 44 & 14.5 & 1.14 & 0.078 \\
\hline 7 & Liverpool & 11.4 & 17 & 15.2 & 0.26 & 0.017 \\
\hline 8 & Manchester & 27.4 & 17 & 12.2 & 0.67 & 0.055 \\
\hline 9 & Southampton & 30.7 & 2 & 12.8 & 1.61 & 0.126 \\
\hline 10 & Milford Haven & 102.54 & 35.65 & 15.37 & 15.35 & 0.742 \\
\hline & Average & & & 4.159 & 0.233 \\
\hline
\end{tabular}

Source: the table was built by the authors on the basis of the information (World Trade Ports)

Table 7

Data on the ports of Canada

\begin{tabular}{|c|c|c|c|c|c|c|}
\hline № & Port name & $Q$ million tons & $L, \mathrm{Km}$ & $H, \mathrm{~m}$ & $k_{e f 1}$ & $k_{i f 3}$ \\
\hline 1 & Vancouver & 45 & 16 & 16.8 & 2.81 & 0.167 \\
\hline 2 & Halifax & 13.5 & 12 & 9.3 & 1.13 & 0.121 \\
\hline 3 & Quebec & 18.1 & 8 & 12 & 2.26 & 0.189 \\
\hline 4 & Montreal & 25 & 23 & 10.7 & 1.09 & 0.102 \\
\hline & Average & 25.4 & 14.75 & 12.2 & 1.822 & 0.145 \\
\hline
\end{tabular}

Source: the table was built by the authors on the basis of the information (World Trade Ports)

Table 8

Data on US ports

\begin{tabular}{|c|l|c|c|c|c|c|}
\hline № & \multicolumn{1}{|c|}{ Port name } & Q million tons & $L, \mathrm{Km}$ & $H, \mathrm{~m}$ & $k_{\text {ef1 }}$ & $k_{\text {ff } 3}$ \\
\hline 1 & Norfolk & 59.9 & 12 & 13.5 & 4.99 & 0.370 \\
\hline 2 & Baltimore & 52.4 & 40 & 13 & 1.31 & 0.101 \\
\hline 3 & Boston & 23.5 & 20 & 12.8 & 1.18 & 0.092 \\
\hline 4 & Long Beach & 43 & 14 & 17 & 3.07 & 0.181 \\
\hline 5 & Los Angeles & 38.7 & 22 & 15 & 1.76 & 0.117 \\
\hline 6 & Mobile & 54.8 & 11.5 & 10.15 & 4.77 & 0.469 \\
\hline 7 & New Orleans & 177 & 26 & 15 & 6.81 & 0.454 \\
\hline 8 & Chicago & 74 & 37 & 9.4 & 2.00 & 0.213 \\
\hline & \multicolumn{1}{|c|}{ Average } & 65.4 & 22.8 & 13.23 & 3.235 & 0.250 \\
\hline
\end{tabular}

Source: the table was built by the authors on the basis of the information (World Trade Ports) 
Table 9

\section{Averaged data on ports in several countries}

\begin{tabular}{|c|l|c|c|c|c|c|c|}
\hline$№$ & Port name & Q million tons & $L, \mathrm{Km}$ & $H, \mathrm{~m}$ & $k_{\text {ef1 }}$ & $k_{\text {if } 3}$ & $k\left(k_{\perp}(e f 1) k_{\perp}\right.$ if3 $)$ \\
\hline 1 & Ukraine & 14.47 & 3.98 & 11.55 & 6.392 & 0.299 & 0.206 \\
\hline 2 & Europe & 102.54 & 35.65 & 15.37 & 4.159 & 0.233 & 0.985 \\
\hline 3 & Canada & 25.4 & 14.75 & 12.2 & 1.822 & 0.145 & 0.871 \\
\hline 4 & USA & 65.4 & 22.8 & 13.23 & 3.235 & 0.250 & 0.936 \\
\hline & Average & 51.95 & 19.3 & 13.1 & 3.902 & 0.232 & 0.749 \\
\hline 6 & Mobile & 54.8 & 11.5 & 10.15 & 4.77 & 0.469 & \\
\hline 7 & New Orleans & 177 & 26 & 15 & 6.81 & 0.454 & \\
\hline 8 & Chicago & 74 & 37 & 9.4 & 2.00 & 0.213 & \\
\hline & Average & 65.4 & 22.8 & 13.23 & 3.235 & 0.250 & \\
\hline
\end{tabular}

Source: the table is built by the authors

From the examination of the tables it follows that the ports of Ukraine in their cargo turnover are inferior to the ports of the countries with which the comparison is made. The length of the berth line of Ukrainian ports and the average depths in the ports are less than in the ports taken for comparison. The relative cargo turnover of Ukrainian ports, per unit length of the berth line and per unit area of the berth wall, respectively, is higher than that of the ports taken for comparison.

For the further integration of Ukraine into the international community, it is necessary to increase the absolute size of Ukrainian ports and to deepen the water area of the ports. The high intensity of Ukrainian ports operation now gives hope for their competitive ability in the future.

\section{Conclusions}

The Ukrainian economy is heavily dependent on international trade. At the same time, the seaports of Ukraine are an extremely important transport window of Ukraine to the world markets, more than $60 \%$ of the Ukrainian export occur through seaports, that is, by sea. In comparison, more than $80 \%$ of the world's trade is by sea. Thus, the efficiency of ports is of utmost importance for the Ukrainian economy in terms of reducing trade costs.

The difficult socio-political situation in the country and the diminishing of the positive image of Ukraine as a reliable partner in international relations, annexation of the Crimean peninsula have led to the breaking of more or less well-established tendencies in the development of the Ukrainian seaports and significantly complicated the assessment of the influence of public administration on this process. There was a dramatic change in the main factors for ensuring the sustainable development of seaports, and economic and political crises came to the fore in the face of hostilities in the east of the country. This significantly affected the volume of cargo turnover, the structure of cargo processing and other indicators.

The performance indicators offered in the work allow to evaluate the activity of the port in different conditions and to compare the activity of different ports with each other. For the ports of Europe, Canada and the USA it is permissible to use the indicator $k_{e f 1}$ instead of the integral indicator $k_{i j 3}$. For the ports of Ukraine such replacement is unacceptable. The comparison with the proposed natural indicators of the Ukrainian and foreign ports efficiency among themselves allows to conclude about the weak development of Ukrainian port infrastructure.

\section{References:}

Chornopyska, N. V. (2008). Metodychni pidkhody otsiniuvannia lohistychnoi diialnosti pidpryiemstva [Methodical approaches of estimation of logistic activity of the enterprise]. Collection of Lviv Polytechnic National University, no. 623, pp. 265-271. (in Ukrainian)

Nikolaeva, N. K., \& Davydova, A. L. (2004). Ob otsenke effektivnosti rabotyi morskih portov [On the evaluation of seaports' performance]. Fundamentalnyie issledovaniya, no. 3, pp. 147-148. (in Russian)

Zhelezkova P.E. (2016). Ekonomicheskaya otsenka urovnya razvitiya portov [Economic assessment of port development level]. Uspehi sovremennoy nauki, vol. 3, no. 11, pp. 133-136. (in Russian)

Entsiklopediya statisticheskih terminov [Encyclopedia of statistical terms]. Moskva: Federalnaya sluzhba gosudarstvennoy statistiki, 2013. (in Russian)

Strategy for the development of Ukrainian seaports for the period until 2038. Project. URL: https://mtu.gov.ua

Ports of Ukraine. Odessa Seaport. URL: https://ports.com/en

World Trade Ports. URL: https://knowledge.allbest.ru

World Trade Ports. URL: https://portsinfo.ru

Trading Ports of England. URL: https://londonmania.ru 